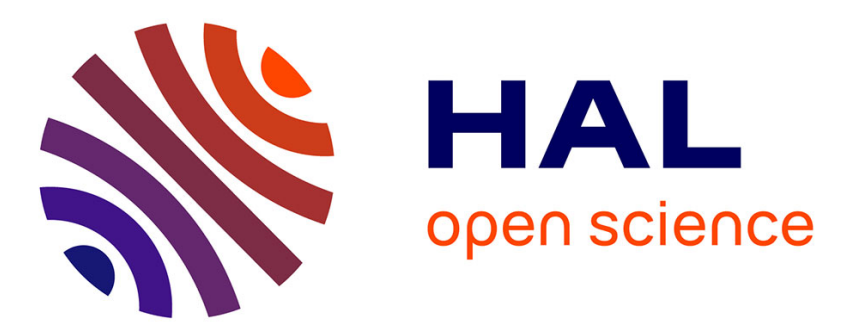

\title{
Challenging the shipper\&apos;s location problem in port studies: An analysis of French AOC wine shipments to the US
}

David Guerrero, Jean-Claude Thill

\section{- To cite this version:}

David Guerrero, Jean-Claude Thill. Challenging the shipper\&apos;s location problem in port studies: An analysis of French AOC wine shipments to the US. Journal of Transport Geography, 2021, 91, pp.102986. 10.1016/j.jtrangeo.2021.102986 . hal-03144046

\author{
HAL Id: hal-03144046 \\ https://hal.science/hal-03144046
}

Submitted on 17 Feb 2021

HAL is a multi-disciplinary open access archive for the deposit and dissemination of scientific research documents, whether they are published or not. The documents may come from teaching and research institutions in France or abroad, or from public or private research centers.
L'archive ouverte pluridisciplinaire HAL, est destinée au dépôt et à la diffusion de documents scientifiques de niveau recherche, publiés ou non, émanant des établissements d'enseignement et de recherche français ou étrangers, des laboratoires publics ou privés. 


\title{
Challenging the shipper's location problem in port studies: An analysis of French AOC wine shipments to the US
}

David Guerrero, Université Gustave Eiffel, IFSTTAR, AME-SPLOTT

Jean-Claude Thill, University of North Carolina at Charlotte, Department of Geography \& Earth Sciences

\begin{abstract}
One of the major issues in port choice and hinterland studies is the identification of the inland origins of containerized shipments. Firms' headquarters, intermediary cross-docking facilities, and the real places of origin of cargo are used interchangeably. This confusion may lead to a wrong perception of the factors affecting port choice decisions. This paper proposes a solution to overcome this problem, by focusing on shipments of French AOC wines (Appellation d'Origine Contrôlée) for which the geographical origin is strictly controlled. The paper also contributes to the port choice and hinterlands literatures by testing three new variables related to the logistical organization of shipments. A conditional logit model is employed to estimate the probability of choosing a port taking in account heterogeneity in the characteristics of shipments and decision makers. The results confirm the importance of inland distance and maritime connectivity, and bring new insight on the impact of logistical organization of shipments.
\end{abstract}

Keywords: port choice, hinterland, container, forwarder, shipment consolidation.

\section{Highlights}

- This study describes individual containerized shipments instead of aggregate trade

- An original method is proposed to overcome the shipper's location problem

- Inland distance remains an important impediment in port choice even for premium cargo

- The preference for frequent services is higher for large shippers and large freight forwarders

- Logistical factors such the use of reefers or multiple-region consolidation also matter 


\section{Introduction}

This paper uses individual shipment data for the analysis of port choice decisions. It aims to contribute to both port choice and hinterland literatures, where "research is at a stage where additional potential variables of port choice are proposed and tested" (Caballé-Valls et al., 2020). Its objectives are both methodological and operational. First, it develops a method for precisely locating the places of origin of shipments. Second, it tests three novel variables on the logistical organization of shipments which may influence port choice decisions.

In this work we revisit two classical factors which are particularly relevant from a transport geography perspective: inland distance and maritime connectivity. Inland distance remains an important impediment, if not the most important impediment, to port choice. It becomes less important when a shipper is equidistant to several ports. In that situation, port attributes such its maritime connectivity become crucial. The trade-off between land distance and the port's maritime connectivity may however vary considerably depending on the characteristics of shipments and decision-makers (Kashiha et al., 2016a, Steven \& Corsi, 2012, Malchow \& Kanafani, 2004). Furthermore, the involvement of freight forwarders in the organization of shipments may also considerably affect the final decision (De Langen, 2007, Tongzon, 2009).

From the perspective of port managers aiming to maintain or to expand port activity, it is important to understand how port choice behavior varies depending on the shipper's location. The perception of the inland distance factor is altered by often limited or inaccurate knowledge of inland origins of shipments. In most databases used in port choice studies firms' headquarters, intermediary crossdocking facilities, and the real places of origin of cargo are used interchangeably. This lack of discrimination results from the complexity of the problem and the barriers to collect accurate statistical information. This confusion may lead to a wrong understanding of how geography affects port choice decisions. To overcome this very crucial issue, this work proposes an analysis focused on cargo for which the geographical origin of production is strictly controlled.

We analyze port choice determinants of individual shipments of French wines to the United States. By using information on a single commodity, the aim is also to gain a more precise understanding of the factors tipping the balance towards one port instead of another, avoiding the heterogeneity resulting for cargo variety (Malchow \& Kanafani, 2004). A novel method of keyword detection is implemented for an accurate identification of the origins of wine shipments instead of the address declared by shippers. This solution also allows the collection of original shipment-level information: the consolidation of shipments from different regions, the involvement of large forwarders and the use of reefer containers. These three factors, which have not been analyzed previously in a detailed manner in the port choice literature, are the second focus of this study.

A conditional logit model is employed for measuring the importance of the factors affecting port choice decisions. We particularly look at the trade-off between geographical proximity and maritime connectivity controlling for the characteristics of shippers and shipments. As a preview of the empirical findings of this work, we find significant differences in the geography of shippers, as compared to the declared shippers' address. The model using the corrected distance measurement confirms the importance of proximity in port choice, even for a premium commodity such wine. We also confirm great heterogeneity on port choice, depending on the characteristics of shippers and shipments. Last but not least, we find that port choice is also affected by the involvement of large 
forwarders, the use of reefer containers, and the ways in which shipments from different regions are bundled.

The conclusions of the paper could be useful for planners and decision makers involved in port development. They could help them have a more accurate appreciation of the factors affecting port choice behavior to eventually adopt changes in prices and services to address specific shipper requirements, or develop incentive programs for forwarders including advantage rates for the installation of consolidation facilities close to the port.

The rest of the paper is structured as foll ows: Section 2 provides a review of the literature. Section 3 presents the data and methods. Section 4 presents the results. Section 5 summarizes the main conclusions.

\section{Literature review}

To contribute to a further understanding of port choice decisions we take as a basis two classical ${ }^{1}$ factors which are particularly relevant from a geographical perspective: inland distance and maritime connectivity. This is complemented by a discussion on the heterogeneity of port choice behavior and shipment characteristics. Even if these three sources of heterogeneity are not spatial, they greatly contribute to shape the geography of port hinterlands. For more exhaustive reviews on port choice and hinterlands see Martinez-Moya et al. (2017) and Guerrero (2021), respectively.

\subsection{Inland distance and maritime connectivity}

In the port choice and hinterland literatures, inland distance has been recognized early as a decisive factor (Malchow \& Kanafani, 2001). Its relevance has been well established in several regional contexts such in Southern Europe (e.g., Moura et al., 2018, Martinez-Pardo et al., 2020), Northern Europe (e.g. Guerrero, 2014, Nazemzadeh \& Vanelslander, 2015), Japan (e.g., Xu \& Itoh, 2019), South America (e.g., Tiller \& Thill, 2017, Vega et al., 2019), India (e.g., Venkitasubramanian and Thill, 2019), or China (e.g. Wang et al., 2018). However, its importance varies considerably depending on the geographical characteristics of the region. In coastal regions or islands, the lack of alternatives to road haulage results in relatively high values of inland friction (i.e. Moura et al., 2018, Xu \& Itoh, 2019). In inland regions equidistant to several ports, differences in transport connectivity may tip the balance from one port to another. ${ }^{2}$

Maritime connectivity reflects how well one port connects to others in the maritime shipping network. It represents an important source of port attractiveness (Slack, 1985, Bird \& Bland, 1988) and is a relevant proxy for freight rates (Wilmsmeier \& Hoffmann, 2008). The concept has gained importance in the two last decades, with the development of network analysis in port geography

\footnotetext{
${ }^{1}$ In the aftermath of World War II these two geographical factors were associated to two streams in port geography, the French one more focused on maritime forelands and the Dutch one discussing hinterland distribution (Ng \& Ducruet, 2014).

${ }^{2}$ Given the overwhel ming domi nance of road in French wine exports, al ternative inland modes have not been considered in the present study. It should be however noted that when considering commodities others than wine, intermodal al ternatives to the road may be determinant, as showed by Guerrero (2019) and GarciaAl onso et al. (2019). Within the port literature there also studies es timating the potential hinterlands of ports, based on time and costs for different transport modes (see, for example, Van Hassel et al. (2016) or Santos \& Soares (2019)).
} 
(e.g., Ducruet, 2013, Pais-Montes et al., 2012) and an increasing demand for 'easily measurable' port performance indicators (Ng \& Ducruet, 2014). The UNCTAD country-level synthetic indicators are probably the best known ones and have been recently developed at the level of ports (UNCTAD, 2019).

Maritime connectivity is measured in different ways. While early studies simply measured it through the frequency of vessel calls, the UNCTAD indicators include as much as five or six components of equal importance. However, these attributes are not necessarily equally relevant for the success of a port (Niérat \& Guerrero, 2019). Accordingly, in this study we have opted to individually consider vessel frequency (e.g. Slack, 1985), directness (Brooks, 1985, Wilmsmeier \& Hoffmann, 2008), and the number of maritime companies operating on a route (Wilmsmeier \& Hoffmann, 2008). These attributes, which have been tested in earlier port choice studies, are considered here as proxies of the number, quality and variety of transport opportunities provided to shippers and forwarders.

\subsection{Variations in port choice behavior}

Large and small shippers value port choice factors differently. While smaller shippers usually base their choice on cost, large shippers put more value on other factors such as frequency and directness of sailing (Brooks, 1985). One explanation to these differences is that large shippers give greater control to carriers, so they are expected to be more sensitive to factors that benefit shipping lines (Steven \& Corsi, 2012, Kashiha et al., 2016b). Furthermore, large shippers, with their own logistics staff, would have a broader vision of the costs of end-to-end transport chains. Small shippers would then focus on cost reduction in the inland segment only ${ }^{3}$, overlooking factors related to maritime connectivity (Tiwari et al., 2003).

Another source of heterogeneity in port choice is the degree of involvement of freight forwarders in the organization of shipments. Despite their importance in the decision-making process they have received little attention in the port choice literature (Talley, 2019). Forwarders are found to be less focused on a single segment than on the whole transport chain, being more concerned with indirect costs such as unreliability, damage, and adverse reputation effects (De Langen, 2007, Tongzon, 2009). Forwarders may also attach more importance to vessel frequency in order to provide more choice to their customers (van den Berg \& De Langen, 2015, Nugroho et al.. 2016). It should be noted however that the involvement of forwarders could vary considerably, from just ensuring paperwork such customs clearance procedures to organizing the whole door-to-door shipment ${ }^{4}$. Furthermore, shippers may outsource the organization of maritime transport to forwarders but de facto continue to take part in port choice decisions (Caballé-Valls et al., 2020).

There may also be differences in port choice depending on the size of forwarders. Large forwarders, providing tens of thousands containers per year in certain routes, are expected to be in a better position to negotiate preferential conditions with multiple shipping lines. Their sensitivity to vessel frequency is expected to be higher, in order to better distribute risks, by spreading the cargo of large customers on several vessels. However, the behavioral differences between small and large

\footnotetext{
${ }^{3}$ The results of a port choice study in Indonesia show the opposite trend: s mall shippers being less sensitive to inland trans port costs than larger ones (Nugroho et al., 2016).

${ }^{4}$ The services provided by forwarders may include space booking on a vessel, non-vessel operating carriers (NVOCCs), orga nizing local and overs eas inland trans port, handling necessary pa perwork and cus tom cl ea rance, delivery and distribution senvice, information service, warehousing, consolidation and other related formalities (Huang et al., 2019).
} 
forwarders remain to be confirmed empirically. In order to bridge this research gap, the current work explores how the involvement of large forwarders impacts port choice.

\subsection{Shipment characteristics and container consolidation}

Port choice decisions may also vary depending on the individual characteristics of shipments. High value cargo is expected to be more sensitive to service quality and less influenced by costs factors (Malchow \& Kanafani, 2004, Guerrero, 2019). The findings of different studies generally confirm the importance of service-related factors for high value cargo, although the impact of distance is not always lower (Kashiha et al., 2016a).

Shipment size also matters, the preference for closer ports being generally lower for small shipments. The deviations to the most direct route to the port tend to be higher for several Less Than Container Load (LCL) shipments. This results from the need to consolidate shipments originated from different locations at the forwarder's warehouse. The longer the distance between the individual shipper locations the higher the probability of deviation from the shortest route to the port. On the contrary Full Container Load (FCL) shipments are mostly carried directly by truck from the shipper's facility to the port, thus increasing the probability of choosing the closest alternative.

Research on the impact of container consolidation on port choice and hinterlands is still nascent. Most of work on shipment consolidation has been carried out within the domain of operational research, with a strong focus on cross-docking operations (Boysen \& Fliedner, 2010). In a recent study, Fan et al. (2019) looked at the conditions under which the (de)consolidation of container imports in the vicinity of a port can allow a reduction of costs and emissions, through a better use of transport capacities and an increased use of alternative modes. They found that the longer the distance to the inland destination, the highest the relevance of the deconsolidation of containers at ports.

Differences are also observed between dry and reefer containers, the latter being more sensitive to distance (Fan et al., 2019). The higher sensitivity to distance may result from the increase of energy usage for cooling the cargo (Cheaitou \& Cariou, 2012) and the need for higher asset utilization of reefers due to their high cost (Rodrigue \& Notteboom, 2014). Within a port choice framework, it is expected that the preference for closer ports would be higher for reefer containers (Hjortnaes et al., 2017). However, no previous work has studied how consolidation issues and the usage of reefer containers affect port choice decisions. Such assessment is carried out in the present work, based on individual shipment data.

\section{Data and method}

\subsection{Data on the shipments and estimation of origins}

The data used in this study describe the wine shipments of 5,194 TEUs from the French regions to European ports during 3 months ${ }^{5}$ (April, July and October) in $2006^{6}$ (figure 1). Maritime exports of

\footnotetext{
${ }^{5}$ The choice of months has been made in order to limit the effects of seas onality regarding the types and value of wine shipments.

${ }^{6}$ In a recent study on France, it has been shown that the hinterland split between ports has only marginally changed since 2006 (Guerrero, 2019). Given the path dependence of port choice, the use of 15 year old data does not seem to be problematic.
} 
French wines to the US primarily transit through 5 European ports, each of which handled at least 50 U.S.-bound twenty-foot equivalent units (TEU) of wine during the sample period. The analysis excludes the remaining ports that collectively handled less than $1 \%$ of all the TEUs of AOC wine during the sample period.

These data are compiled from two sources: the U.S. Customs and Border Protection Automated Manifest system and manifests submitted at the various ports. The original documents are partially corrected for inconsistencies and supplemented by a third-party data supplier: PIERS. The resulting database includes attributes of each shipment including the bill of lading, a description of the commodity being shipped, shipment quantity in TEUs, the maritime carrier, European and U.S. ports of transit, and shippers' address. In many cases, the information on shipper's address does not necessarily correspond to the physical origin of the goods nor to the place where the container was staffed.

This work proposes a solution to the shippers' location problem by focusing on goods for which the geographical origin is strictly controlled. In France, this is done through a certification system for agricultural products called Appellation d'Origine Contrôlée (AOC). Amongst the French AOC products, wine is the most important in terms of volume. It appears as a particularly relevant case for understanding port choice for two main reasons. On the one hand, it is produced in many regions spread across the national territory, providing a variety of observation points from which port alternatives can be compared. On the other hand, as a high value added good, AOC wine is expected to be less sensitive to transport cost and could allow a better appreciation of factors others than inland distance.

Information on the $\mathrm{AOC}$ regions of origin has been reconstituted through keyword detection, using commodity descriptions and shipper names. This procedure involved as a first step the inventory of about a thousand single wine-related keywords to which $A O C$ regions have been individually assigned. In a second step, each shipment was associated to one or several AOC regions. When a single shipment contained wines from several AOC regions, it was divided in shipments of equal volume.

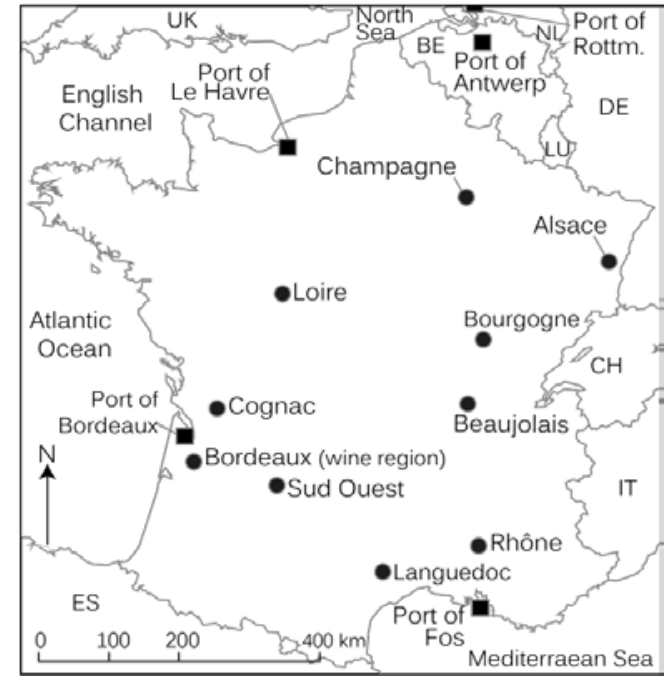

Figure 1 Map of the main $A O C$ regions and ports

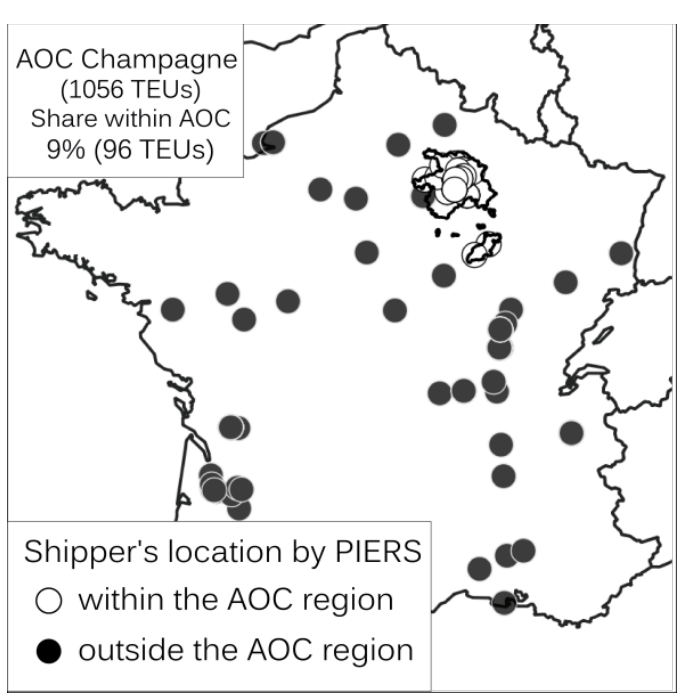

Figure 2 Map of the shippers' addre sses for AOC Champagne 
The spatial distribution of shipments resulting from this estimation differs from the one obtained from the shipper's address field in the original database. Figure 2 shows that only $9 \%$ of the volumes of Champagne had a declared shipper address within the limits of the Champagne AOC region. Table $1\left(2^{\text {nd }}\right.$ column) reports the same information for the rest of $A O C$ regions. The matching between shipper's address (in the original database) and the AOC region (estimated by authors) greatly varies, ranging from 9\% (Champagne, Beaujolais) to $81 \%$ (Bourgogne). Overall, the locations provided by the original database corresponded to estimations based on keyword extraction and processing for $47 \%$ of the TEUs only. As seen in Figure 3, the correlation with shipment size is moderate.

Table 1 Breakdown of cont ainer throughput by AOC region and share of address

$\begin{array}{cccc}\text { Number of } & \begin{array}{c}\text { Share of TEUs for which } \\ \text { AOC matches with the }\end{array} & \begin{array}{c}\text { Shipment } \\ \text { size, TEUs }\end{array} & \begin{array}{c}\text { Shipment } \\ \text { size, TEUs }\end{array} \\ \text { TEUs } & \text { shippers' address } & \text { (median) } & \text { (average) }\end{array}$

$\begin{array}{lcccc}\text { Champagne } & 1056 & 9 \% & 2.00 & 1.48 \\ \text { Bourgogne } & 801 & 84 \% & 0.67 & 0.76 \\ \text { Bordeaux } & 718 & 71 \% & 0.51 & 0.88 \\ \text { Rhône } & 489 & 63 \% & 0.52 & 0.81 \\ \text { Cognac } & 282 & 25 \% & 1.00 & 0.96 \\ \text { Languedoc } & 277 & 55 \% & 0.51 & 0.96 \\ \text { Loire } & 275 & 49 \% & 0.33 & 0.60 \\ \text { Sud Ouest } & 187 & 10 \% & 1.00 & 1.19 \\ \text { Beaujolais } & 133 & 9 \% & 0.67 & 0.81 \\ \text { Alsace } & 98 & 62 \% & 0.50 & 0.82 \\ \text { Other AOC } & 99 & 35 \% & 0.01 & 0.21 \\ \text { Total } & 4414 & 47 \% & 0.67 & 0.85\end{array}$

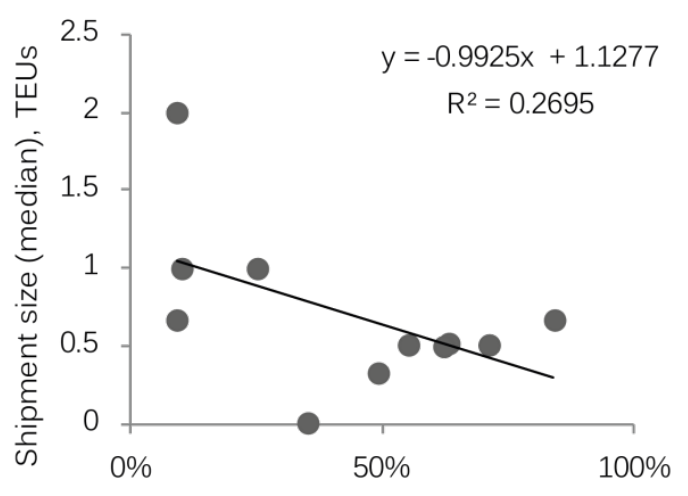

a.

Share of TEUs for which AOC matches with the shipper address

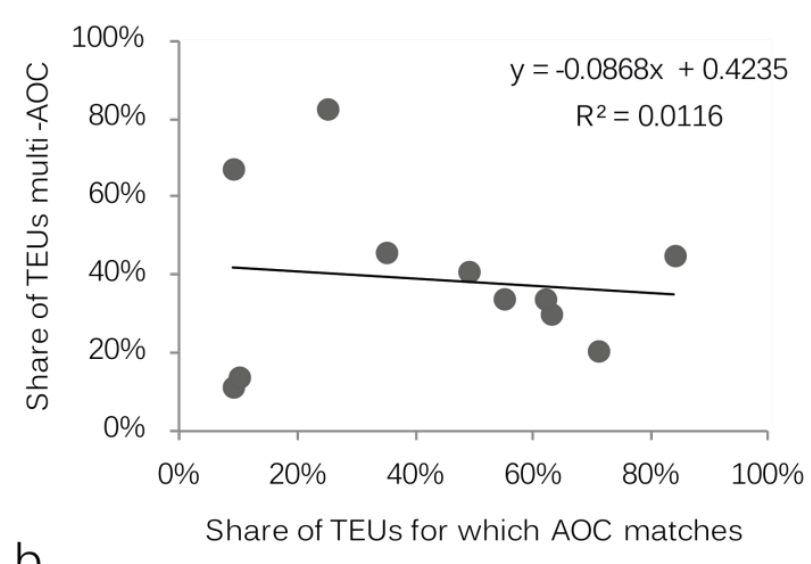

with the shipper address

Figure 3. Graphs comparing the Share of TEUS for which AOC matches with the shipper address with: (a) Shipment size, and, (b) Sh are of multi-AOC shipments 
Table 1 also reports the number of sampled shipments for each AOC region. The volumes were geographically concentrated, with the top four $\mathrm{AOC}$ regions generating about two thirds of the wine exports. The median size of shipments was small $(0.67 \mathrm{TEU})$ overall, but greatly varied between $A O C$ regions, ranging from 0.01 (other $A O C$ regions) to 2 (Champagne).

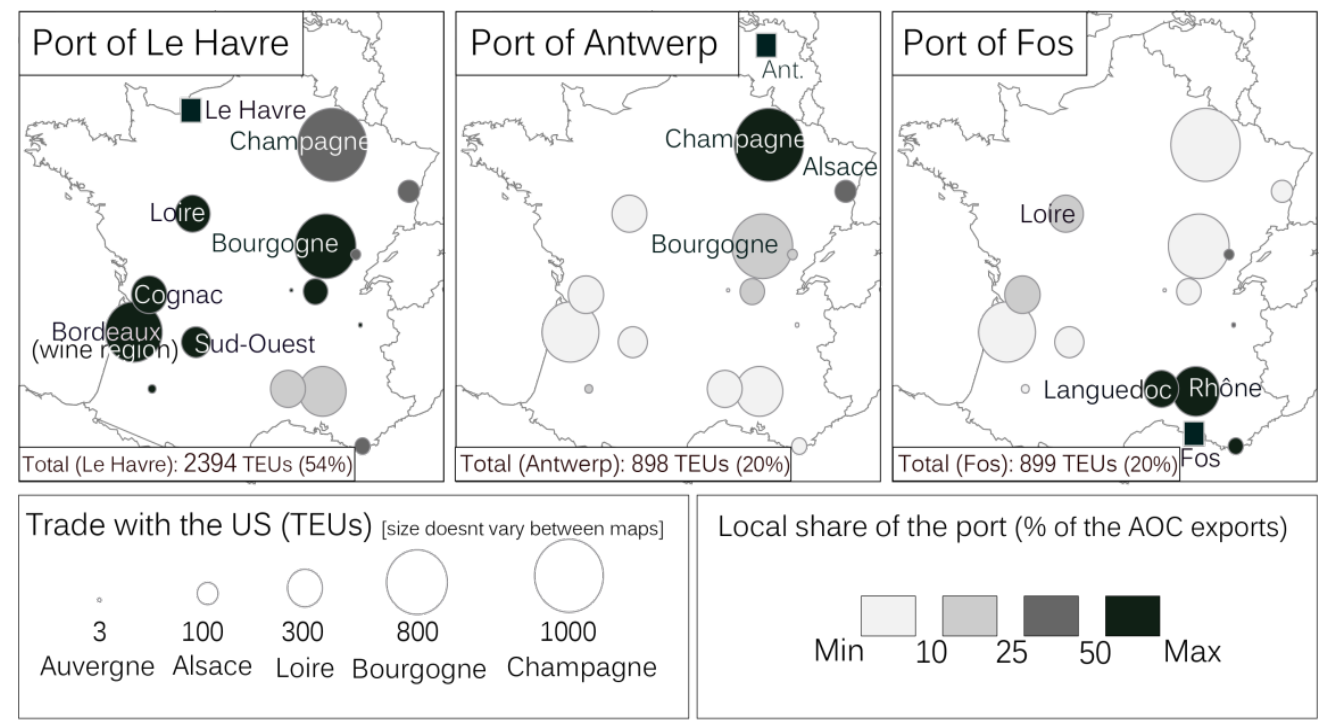

Note: A small part of the wine trade from France to the US passes through ports which are not represented here. Rotterdam and Bordeaux handle respectively 167 TEUs and 56 TEUs (4\% and $1 \%$ of the total).

Figure 3 Map s of the sampled throughput by AOC region and share of the main ports

Figure 3 depicts the main ports and $A O C$ regions. The majority of $A O C$ wine ${ }^{7}$ regions are located in the South-East half of France, except Champagne and Loire. By contrast, ports are mostly located in the North and the West. Figure 3 maps the sampled volumes by AOC region and the local shares of ports. The port of Le Havre handled $54 \%$ of the volumes, Antwerp and Fos $20 \%$ each. No other port was selected for more than $4 \%$ of the volumes. The port of Le Havre handled the majority of volumes in many of the top AOC regions, particularly in the North and the West. The ports of Antwerp and Fos were only prominent in the North-East and South-East, respectively.

\subsection{Conditional logit model}

A conditional logit model was used to examine the preferences of shippers and forwarders relating to port selection. This type of model is common in port-selection studies (see, for example Malchow \& Kanafani, 2004; Kashiha et al., 2016a). For each shipment, the model estimates the probabilities of choosing each one of the five port alternatives, based on transport costs and a set of variables related to the characteristics of ports. The selected port is the one that provides the highest utility, but it cannot be predicted with certainty and is therefore estimated probabilistically.

In a random utility framework (McFadden, 1974), the utility of a port $j$ for a shipper $n$ is

$$
u_{n j}=v_{n j}+\varepsilon_{n j}
$$

\footnotetext{
${ }^{7}$ Exceptionally, vol umes of AOC Cognac (spirit) are included in the analysis but only when they are part of shipments containing wine as well.
} 
where $v_{n j}$ represents the deterministic component of utility and it is known through the variables $x_{n j}$. The term $\varepsilon_{n j}$ is stochastic. Therefore the probability that a shipper $j$ chooses a port $n$ is:

$$
p_{n j}=\frac{\exp \left(u_{n j}\right)}{\sum_{\mathrm{k}} \exp \left(u_{n k}\right)}
$$

in which $u_{n j}$ is a linear function of observable variables that vary with the characteristics of alternatives, $u_{n j}=\beta \mathrm{x}_{n j}$. Assuming that there are $\mathrm{m}$ factors affecting port selection, then $v_{n j}$ is:

$$
v_{n j}=\beta_{1} X_{n j}^{1}+\beta_{2} X_{n j}^{2}+\beta_{3} X_{n j}^{3}+\cdots \beta_{m} X_{n j}^{m}
$$

Theoretically, this model estimates the utility of a port for a shipper by comparing its characteristics to those of the four other ports. For each shipment, there are five cases, four having a dependent variable equal to zero and the remaining is equal to one. Shipment characteristics do not vary over alternatives. Coefficients were determined from the data through Maximum Likelihood Estimation (MLE) with the Newton-Raphson algorithm, on Base SAS Software.

It should be noted that the reality of the containerized exports of the French $\mathrm{AOC}$ wine differs from the ideal framework of the discrete choice models. French shippers of wine are rarely decisionmakers within the context of deep-sea transport chains. Most of the transactions are ex-works, meaning that the overseas buyers often assume the cost and the responsibility of transporting the wine from the seller's facility in France (Saglietto et al., 2016). Freight forwarders are hired to plan the most appropriate routes for shipments, including port choice and the selection of land and sea transport providers. Their port choice decisions will also be greatly influenced by strategies of shipping lines, particularly with regard to the deployment of vessels of different sizes, their frequency and the ports of call.

Table 2 De scriptive statistics

$\begin{array}{llrrrr} & \text { Measurement } & \text { Mean } & \text { Std Dev } & \text { Min } & \text { Max } \\ \text { Distance } & \text { In km } & 4.62 & 2.02 & 0.02 & 9.79 \\ \text { Vessel frequency } & \text { Weekly services } & 6.34 & 4.04 & 0.1 & 12 \\ \text { Shipping lines } & \text { Number } & 9.83 & 3.36 & 1 & 13 \\ \text { Shipment size } & \text { Number of TEUs } & 0.85 & 0.94 & 0.01 & 16.04 \\ \text { Shipper's size } & \text { Number of TEUs } & 100.77 & 178.31 & 0.01 & 550.51 \\ \text { Value per unit } & \text { USD / kg } & 5.62 & 3.25 & 0.22 & 29.39 \\ \text { Reefer } & \text { Dummy } & 0.11 & 0.31 & 0 & 1 \\ \text { Transshipment } & \text { Dummy } & 0.10 & 0.29 & 0 & 1 \\ \text { AOC consolidation } & \text { Dummy } & 0.39 & 0.49 & 0 & 1 \\ \text { Large Forwarder } & \text { Dummy } & 0.26 & 0.44 & 0 & 1\end{array}$

To reflect the characteristics of transport chains, the explanatory variables in the model include the distance from each of the $A O C$ regions to each seaport; the frequency of direct maritime services; and the number of shipping lines operating on the route between the port and the corresponding port range in the U.S. (Atlantic, Pacific, Gulf). The regression is weighted by the shipment size (in TEU). Characteristics of shipments (size, value, reefer, multiple-region consolidation) and shippers (shipper 
size, involvement of large freight forwarder) have been taken into account. Table 2 reports descriptive statistics for the sample of 5,194 shipments. The inland distance as the crow flies has been calculated from the largest urban areas within the $A O C$ regions to the seaports. The two variables describing the containerized transport supply between European ports and the US port ranges are based on 2007 data compiled by MDS Transmodal (https://www.mdst.co.uk) from the different maritime companies. Data on AOC consolidation, reefer and involvement of large forwarder have been obtained through keyword-detection method from raw PIERS data.

It is important to mention two variables that are not included in the model but may have an impact on port choice: vessel size and freight rates. Former works suggested that vessel size may play a role in port choice (Malchow \& Kanafani, Steven \& Corsi, 2012). The main explanations are that maritime companies using large vessels may provide more available slots per port call, thus increasing port attractiveness for shippers and forwarders. This assumption could be reasonable on the long run (shipping lines would only call at ports where a large number of movements can be done) but on the short run things are more complex, and the number of slots available may greatly depend on negotiations with local shipping agents and the stability of the local demand. In other words, for shipping lines not all the ports in a route are equally important.

Another hypothesis relating vessel size and port choice is that when shipping lines achieve higher economies of scale, they may transfer part of the cost savings to their customers. However, it has been argued that the extent to which savings are passed to shippers and forwarders depends on the level of competition between lines (Hoffmann, 2012). Independently of the vessel size, it seems reasonable to think that the more shipping lines compete for the inland clients, the lower the freight rates paid by shippers are likely to be (Wilmsmeier and Hoffmann, 2008).

The second variable is freight rates charged by shipping lines at different ports. A high cost of maritime transport could make a port less attractive for shippers and forwarders. However ocean freight rates are difficult to measure precisely, the rates vary considerably by customer even for the same port, depending on its importance to the shipping line (Slack \& Gouvernal, 2011). This brings into question the appropriateness of freight rates quotations, publicly available on internet, and frequently used in quantitative port choice analyses (see, for example, Martinez-Pardo et al., 2020).

\section{Results}

The conditional logit model provides estimations of how different characteristics of shipments contribute to the explanation port choice decisions. The estimates for the coefficients of each variable are provided in table 3 . As found in previous studies, the coefficients related to maritime connectivity have positive sign, while inland distance has a negative one. The results can be interpreted as follows.

Table 3 Results of a conditional logit model of port choice (Signi ficant at $* 10 \%, *_{5}^{*} \%$, ${ }^{* *} * 1 \%$ level)

$\begin{array}{llcc} & \text { Estimate }(\beta) & \text { Std Error } & \text { Std. Estimate } \\ \text { Distance } & -0.3237^{\star \star \star} & 0.0427 & -7.5857 \\ \text { Vessel frequency } & 0.3712^{\star \star \star} & 0.0588 & 6.3113 \\ \text { Shipping lines (Number) } & 0.8699^{\star \star \star} & 0.0417 & 20.8255 \\ \text { Distance * Vessel frequency } & -0.0275^{\star \star \star} & 0.0061 & -4.5008\end{array}$




$\begin{array}{llll}\text { Distance * Shipping lines (Number) } & 0.0025 & 0.0061 & 0.4137 \\ \text { Distance * Shipment size } & -0.0292^{\star \star \star} & 0.0087 & -3.3609 \\ \text { Distance * Shipper's size } & -0.0009^{\star \star \star} & 0.0001 & -7.7383 \\ \text { Distance * Value per unit } & -0.0064 & 0.0044 & -1.4434 \\ \text { Distance * Transshipment (dummy) } & -0.0751^{\star} & 0.0394 & -1.9088 \\ \text { Distance * Reefer (dummy) } & -0.1848^{\star \star \star} & 0.0425 & -4.3451 \\ \text { Distance * AOC consolidation (dummy) } & 0.3138^{\star \star \star} & 0.0284 & 11.0504 \\ \text { Distance * Large forwarder (dummy) } & 0.0670^{\star \star} & 0.0283 & 2.3661 \\ \text { Vessel frequency * Shipping lines (Number) } & -0.0402^{\star \star \star} & 0.0045 & -8.8698 \\ \text { Vessel frequency * Shipment size } & 0.0522^{\star \star \star} & 0.0072 & 7.2185 \\ \text { Vessel frequency * Shipper's size } & 0.0012^{\star \star *} & 0.0001 & 18.0088 \\ \text { Vessel frequency * Value per unit } & 0.0051^{\star \star} & 0.0025 & 2.0010 \\ \text { Vessel frequency * Transshipment (dummy) } & -0.5678^{\star \star *} & 0.0387 & -14.6602 \\ \text { Vessel frequency * Reefer (dummy) } & 0.1359^{\star \star \star} & 0.0275 & 4.9350 \\ \text { Vessel frequency * AOC consolidation (dummy) } & -0.0921^{\star \star \star} & 0.0189 & -4.8757 \\ \text { Vessel frequency * Large forwarder (dummy) } & 0.0943^{\star \star *} & 0.0192 & 4.9008\end{array}$

Pseudo-R ${ }^{2}$

The preference for ports rapidly decreases with distance, even for high-value added goods such fine wines. Increasing inland distance by $100 \mathrm{~km}$ over the sample mean reduces the odds of selecting a particular port by $28 \%$. The impact of distance is even stronger for indirect connections, when the container is transshipped at a hub port. There is significant heterogeneity in the impact of distance depending on the shippers' size and shipment characteristics. The interactions with distance estimate the additional weight that decision makers put on distance in different situations. It shows that the preference for closer port options increases with shipment size and shippers' size, confirming the findings of previous studies. However, the interaction coefficient with value is not significant, maybe because of the overall high value of wine shipments. The interaction of distance with the use of reefer containers, usually containing premium wines, shows that in this segment shippers put more weight on proximity. The effect of distance is only attenuated when there is multiple-region consolidation or when a large freight forwarder is involved.

When a region is equidistant to several ports, factors related to maritime connectivity play an important role in selecting a port to ship out of Europe. The impact of vessel frequency is lower than the number of companies, which may result from small differences in vessel frequency between the Northern Range ports to the U.S. Indeed, a port choice factor could be important, but not salient if variation between ports was not present (Brooks, 1985). The interaction coefficients show that vessel frequency is more positively valued by large shippers and large forwarders. The preference for more frequent services also increases with shipment size and value, and when reefer containers are used. Frequency is slightly less positively perceived when shipments from different $A O C$ regions are consolidated within a same container. We found a negative relation between port choice and vessel 
frequency for indirect shipments (with transshipment). This probably results from the fact that shipments are systematically routed through feeder ports, avoiding the main ports which concentrate most of the direct services.

The high value of the coefficient associated with distance confirmed that it remains an important barrier for port choice, even when cargo origins are strictly controlled. In general, ports attract shipments from close $\mathrm{AOC}$ regions. The negative sign of the interaction coefficient between distance and shipper size suggests that large shippers, with frequent shipments have a greater awareness on inland transport costs. On the contrary, large forwarders display less sensitivity to inland distance, suggesting that they may have a wider vision of the costs of the global transport chain, beyond the sole inland transport costs. The effect of distance for multiple-region shipments is also lower, indicating that the port choice decision results from a more complex trade-off including, for example, the location of the other wine regions, and the existing logistics networks of the forwarders.

Findings also highlight the importance of maritime connectivity as an important attractor for ports. A port with more frequent ship calls would result in lower inventory costs, since the cargo on average will be waiting less time, and therefore they will reach their destinations sooner (Talley \& Ng, 2013). Vessel frequency is valued more positively by large forwarders, maybe because it provides them with more choices for moving the cargo and to quickly respond to the needs of their customers (Tongzon, 2009, De Langen, 2007, Bird \& Bland, 1988). For large forwarders providing services to large firms on a regular basis, frequency could be a mean to spread the containers of their customers' cargo between different vessels, therefore limiting the risks.

The sensitivity to frequency is slightly lower for containers with shipments from multiple AOC regions. This goes against our expectations for containers which were supposed to be more time-sensitive. Maybe when urgent and non-urgent shipments are consolidated within a same container, the characteristics of the non-urgent shipments are taken as a reference for routing the cargo. For reefers, which are expected to be more time sensitive, the sensitivity to vessel frequency is higher.

\section{Conclusion}

The objective of this paper was twofold: (1) to develop a novel method for accurately locating the places of origin of shipments, (2) to test three original variables of the logistical organization of shipments which may influence port choice decisions.

With regard to the first objective, the proposed method, based on the recognition of the places of origin through keyword detection, allowed an accurate estimation of the origins of containerized shipments, providing a sound basis for the study of port choice decisions. It showed that there is a considerable gap between the origins estimated through keyword detection and the addresses provided in the original database. This confirms the interest of the method to identify the real places of origin of shipments. The size of the deviations varied considerably however between AOC regions, so the gap may also differ for cargo other than wine. All in all, this study confirmed, on the basis of accurate location data, the importance of factors previously studied by scholars such inland distance and maritime connectivity. The importance of inland distance in port choice has been confirmed for a premium cargo such AOC wine. Given the results of previous research (e.g. Guerrero, 2019), it can reasonably be expected that the overall influence of distance on cargo of lower value is even higher. When a region is equidistant to several ports, factors related to maritime connectivity matter. In that 
situation, the number of shipping lines and the frequency of services greatly increase the odds for a port to be chosen. In many of the largest AOC regions, the port of Le Havre seems to offer an interesting trade-off between inland distance and maritime connectivity. This is an important result, which relativizes the importance of the port of Antwerp, which is only prominent in the NorthEastern market.

With regard to the second objective, we showed, for the first time, that factors related to the logistics organization of shippers and freight forwarders may also affect port choice decisions. Large forwarders seem to be less sensitive to inland distance, suggesting that they may have a broader view of the costs of the global transport chain, beyond the sole inland transport costs. Therefore, the effect of distance for multiple-region shipments is al so lower, indicating that the port choice decision results from a more complex trade-off including, for example, the location of other wine regions, and the overall geographical organization of each forwarder. Finally, when the shipments are carried within reefer containers, the preference for closer ports is higher. This may result from higher inland empty positioning costs of reefer containers as compared to dry containers (Hjortnaes et al., 2017). The integration of these factors in future models should help to better understand the factors that tip the balance, particularly when it comes to the competition between the ports of Le Havre and Antwerp.

Given the importance of shipper and cargo heterogeneity, more research is needed in several directions. The case of wine shipments only represents a small part of all containerized shipments. The sensitivity to port choice factors discussed in this paper may differ when considering shipments of lower value. Another promising line of research would be to expand this study to other European countries and AOC products. Perishable products, such cheese, may provide interesting insight on the variations in port choice for reefer containers. Finally the comparison of the results with more recent data would allow analyzing the evolution of port choice decisions, notably after the introduction of mega-vessels and the consolidation of shipping lines.

In terms of managerial implications, our results suggest that small, multiple-region shipments are less captive to ports. To maintain or conquer this cargo flows, port authorities may encourage LCL consolidation activities into the port area through attractive rents (Fan et al., 2019). The development of value-added services such as labeling, kitting, repackaging and quality control may also be an option. 


\section{References}

Bird, J., \& Bland, G. (1988). Freight forwarders speak: the perception of route competition via seaports in the European Communities Research Project. Part 1. Maritime Policy \& Management, 15(1), 35-55.

Boysen, N., \& Fliedner, M. (2010). Cross dock scheduling: Classification, literature review and research agenda. Omega, 38(6), 413-422.

Brooks, M. R. (1985). An alternative theoretical approach to the evaluation of liner shipping: Part 2. Choice/Criteria. Maritime Policy and Management, 12(1), 145-155.

Caballé-Valls, J., de Langen, P. W., Garcia-Alonso, L., \& Vallejo-Pinto, J. A. (2020). Understanding port choice determinants and port hinterlands: Findings from an empirical analysis of Spain. Maritime Economics \& Logistics, 22(1), 53-67.

Cheaitou, A., \& Cariou, P. (2012). Liner shipping service optimisation with reefer containers capacity: An application to northern Europe-South America trade. Maritime Policy \& Management, 39(6), 589602.

De Langen, P. W. (2007). Port competition and selection in contestable hinterlands; the case of Austria. European Journal of Transport and Infrastructure Research, 7(1), 1-14.

Ducruet, C. (2013). Network diversity and maritime flows. Journal of Transport Geography, 30, 77-88.

Fan, Y., Behdani, B., Bloemhof-Ruwaard, J., \& Zuidwijk, R. (2019). Flow consolidation in hinterland container transport: An analysis for perishable and dry cargo. Transportation Research Part E: Logistics and Transportation Review, 130, 128-160.

Garcia-Alonso, L., Monios, J., \& Vallejo-Pinto, J. A. (2019). Port competition through hinterland accessibility: the case of Spain. Maritime Economics \& Logistics, 21(2), 258-277.

Guerrero, D. (2014). Deep-sea hinterlands: Some empirical evidence of the spatial impact of containerization. Journal of Transport Geography, 35, 84-94.

Guerrero, D. (2019). Impacts of transport connections on port hinterlands. Regional Studies, 53(4), 540-549.

Guerrero, D. (2021). A global analysis of hinterlands from a European perspective. In Kato S., Shibasaki, R., Ducruet, C. (Eds.) Global Logistics Network Modelling and Policy: Quantification and Analysis for International Freight, Elsevier, 31-46.

Hjortnaes, T., Wiegmans, B., Negenborn, R. R., Zuidwijk, R. A., \& Klijnhout, R. (2017). Minimizing cost of empty container repositioning in port hinterlands, while taking repair operations into account. Journal of Transport Geography, 58, 209-219.

Hoffmann, J. (2012). Corridors of the Sea: An investigation into liner shipping connectivity. Les corridors de transport (sous la direction de Yann Alix), Editions EMS, Caen, 263-276.

Huang, S. T., Bulut, E., \& Duru, O. (2019). Service quality evaluation of international freight forwarders: an empirical research in East Asia. Journal of Ship ping and Trade, 4(1), 14. 
Kashiha, M., Thill, J. C., \& Depken II, C. A. (2016a). Shipping route choice across geographies: Coastal vs. landlocked countries. Transportation Research Part E: Logistics and Transportation Review, 91, 114.

Kashiha, M., Depken, C., \& Thill, J. C. (2016b). Border effects in a free-trade zone: Evidence from European wine shipments. Jo urnal of Economic Geography, 17(2), 411-433.

Malchow, M., \& Kanafani, A. (2001). A disaggregate analysis of factors influencing port selection. Maritime Policy \& Management, 28(3), 265-277.

Malchow, M. B., \& Kanafani, A. (2004). A disaggregate analysis of port selection. Transportation Research Part E: Logistics and Transportation Review, 40(4), 317-337.

Martínez-Moya, J., \& Feo-Valero, M. (2017). Port choice in container market: a literature review. Transport Reviews, 37(3), 300-321.

Martínez-Pardo, A., Orro, A., \& Garcia-Alonso, L. (2020). Analysis of port choice: A methodological proposal adjusted with public data. Transportation Research Part A: Policy and Practice, 136, 178-193.

McFadden, D. (1974). Analysis of Qualitative Choice Behavior. Zarembka, P.(ed.): Frontiers in Econometrics.

Moura, T. G. Z., Garcia-Alonso, L., \& del Rosal, I. (2018). Influence of the geographical pattern of foreign trade on the inland distribution of maritime traffic. Journal of Transport Geography, 72, 191200.

Nazemzadeh, M., \& Vanelslander, T. (2015). The container transport system: Selection criteria and business attractiveness for North-European ports. Maritime Economics \& Logistics, 17(2), 221-245.

Ng, A. K., \& Ducruet, C. (2014). The changing tides of port geography (1950-2012). Progress in Human Geography, 38(6), 785-823.

Niérat P. \& Guerrero D. (2019). UNCTAD maritime connectivity indicators: review, critique and proposal, UNCTAD Transport and Trade Facilitation Newsletter, 84.

Nugroho, M. T., Whiteing, A., \& de Jong, G. (2016). Port and inland mode choice from the exporters' and forwarders' perspectives: Case study-Java, Indonesia. Research in transportation business \& management, 19, 73-82.

Pais-Montes, C., Seoane, M. J. F., \& Laxe, F. G. (2012). General cargo and containership emergent routes: A complex networks description. Transport Policy, 24, 126-140.

Rodrigue, J. P., \& Notteboom, T. (2014). The cold chain and its logistics. Webpage derived from JP Rodrigue, Reefers in North American Cold Chain Logistics: Evidence from Western Canadian Sup ply Chains. Calgary: The Van Horne Institute, University of Calgary. Available at: https://people.hofstra. edu/geotrans/eng/ch5en/appl5en/ch5a5en. html (accessed 20 February 2017).

Saglietto, L., Fulconis, F., Didier, B., De Almeira Goes, J., Forradellas, R. (2016) Wine industry Supply Chain (WSC) modeling: an Argentina-France comparison. Supply Chain Forum: An International Journal, Vol 17, Issue 2, pp. 55-67. 
Santos, T. A., \& Soares, C. G. (2019). Container terminal potential hinterland delimitation in a multiport system subject to a regionalization process. Journal of Transport Geography, 75, 132-146.

Slack, B. (1985). Containerization, inter-port competition, and port selection. Maritime policy and management, 12(4), 293-303.

Slack, B., \& Gouvernal, E. (2011). Container freight rates and the role of surcharges. Journal of Transport Geography, 19(6), 1482-1489.

Steven, A. B., \& Corsi, T. M. (2012). Choosing a port: An analysis of containerized imports into the US. Transportation Research Part E: Logistics and Transportation Review, 48(4), 881-895.

Talley, W. K., \& Ng, M. (2013). Maritime transport chain choice by carriers, ports and shippers. International Journal of Production Economics, 142(2), 311-316.

Talley, W. K. (2019). Determinants of cargo port choice by port service providers. Transportation Research Part E: Logistics and Transportation Review, 132, 48-50.

Tiller, K. C., \& Thill, J. C. (2017). Spatial patterns of landside trade impedance in containerized South American exports. Journal of Transport Geography, 58, 272-285.

Tiwari, P., Itoh, H., \& Doi, M. (2003). Containerized cargo shipper's behavior in China: a discrete choice analysis. Journal of Transportation and Statistics, 6, 71-86.

Tongzon, J. L. (2009). Port choice and freight forwarders. Transportation Research Part E: Logistics and Transportation Review, 45(1), 186-195.

UNCTAD (2019) Review of Maritime Transport, United Nations, Geneva, https://unctad.org/en/PublicationsLibrary/rmt2019_en.pdf

Van den Berg, R., \& De Langen, P. W. (2015). Assessing the intermodal value proposition of shipping lines: Attitudes of shippers and forwarders. Maritime Economics \& Logistics, 17(1), 32-51.

Van Hassel, E., Meersman, H., Van de Voorde, E., \& Vanelslander, T. (2016). Impact of scale increase of container ships on the generalised chain cost. Maritime Policy \& Management, 43(2), 192-208.

Vega, L., Cantillo, V., \& Arellana, J. (2019). Assessing the impact of major infrastructure projects on port choice decision: The Colombian case. Transportation Research Part A: Policy and Practice, 120, 132-148.

Venkitasubramanian, K., and Thill, J.-C. (2019). Effect of privatization and inland infrastructural development on India's container port dynamics. Asian Journal of Shipping and Logistics, 35(4), $220-$ 229.

Wang, L., Goodchild, A., \& Wang, Y. (2018). The effect of distance on cargo flows: a case study of Chinese imports and their hinterland destinations. Maritime Economics \& Logistics, 20(3), 456-475.

Wilmsmeier, G., \& Hoffmann, J. (2008). Liner shipping connectivity and port infrastructure as determinants of freight rates in the Caribbean. Maritime Economics \& Logistics, 10(1-2), 130-151. 
Xu, H., \& Itoh, H. (2019). Path dependence in port choice: some quasi-experimental evidence. Applied Economics Letters, 1-8. 